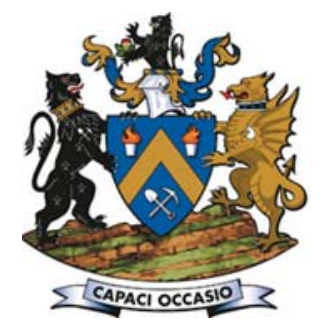

\title{
Improved ultrafine coal dewatering using different layering configurations and particle size combinations
}

\author{
by M.E.C. Snyman ${ }^{1}$ and N. Naudé ${ }^{1}$
}

\section{Synopsis}

Coal fines produced during processing are difficult to dewater and result in a lower quality product and consequent lower value. A South African coal mine experiences severe difficulties with belt filter dewatering operations due to the presence of fines reporting from the thickener underflows. Plant 2 currently handles super-fine particles of size $-34 \mu \mathrm{m}$ and has low belt filter efficiency: excessive moisture retention lowers the product quality and strains downstream processing. It was necessary to determine an alternative method for dewatering these fines. Blending of fine material with coarser material was proposed as a solution. The effect of coal particle size and layering during ultrafines belt filter dewatering was evaluated using various blends of the fine Plant 2 material with coarser Plant 1 material. The best layering arrangement of the two materials and its optimum blend required to achieve reduced filter cake moisture content was determined in practise using a vacuum filter to simulate belt filtration. A blend of the two materials gave improved dewatering efficiency for the belt filters compared with that of the Plant 2 material alone. The best layering configuration was with Plant 2 material at the bottom and Plant 1 material on top. The optimum blend for industrial applications comprised 48\% fines from Plant 2.

Keywords

ultrafine coal, dewatering, belt filter, vacuum filter, moisture content.

\section{Introduction}

Fines are produced during the processing of coal. It is estimated that 2 to $3 \%$ of run-ofmine coal reports to the ultrafine portion $(-100 \mu \mathrm{m})$ (le Roux, 2005). The particle size of coal is inversely proportional to the amount of water adsorption, so smaller particles adsorb more moisture. Moisture removal requires either mechanical processes or thermal drying: mechanical processes are less expensive, but the fines still have high moisture retention. Discarding of fines leads to economic losses, so it is essential that they be dewatered so that they can then be sold as a product: fines need to be treated for both resource management and conservation reasons (Kenney, 1994). Removal of free surface moisture from ultrafine coal particles using a belt filter therefore remains a process that needs to be continuously improved. Ultrafine coal originating from a thickener underflow is known to be difficult to dewater owing to factors such as filter cloth blockage and moisture retention due to clogging. Mixing of finer and coarser materials has been proposed to deliver better dewatering efficiency and improved the quality of the recycled water (Kenney, 1994).

This project aimed to solve belt filter problems associated with ultrafine materials at a South African coal mine. The plant operates two belt filter plants: the thickener underflow solids feed to Plant 1 is relatively coarse, having a particle size of approximately $75 \mu \mathrm{m}$, while that of Plant 2 is fine, approximately 34 $\mu \mathrm{m}$. The optimum blend proportions and layering arrangements of the two materials on a belt filter were assessed to compare dewatering efficiency and the quality of the filter cake and filtrate produced. Factors influencing the final moisture content of a filter cake generated by layering super-fine and coarser material on a belt filter to maximize water removal efficiency were experimentally determined using different layering configurations. The optimum fines content of the blend was then determined.

\section{Background}

\section{Moisture content}

Insufficient dewatering influences the quality of the final coal product, especially in the thermal coal industry. The moisture content of coal is strongly governed by the quality specifications and economic possibilities for a plant. A lower moisture content results in a higher quality product and hence a higher sales price, so it is essential that continuous improvement of dewatering technologies is undertaken (de Korte, 2008). A previous study showed that the proportion of $-75 \mu \mathrm{m}$ material in the belt filter feed exhibited a linear

1 Department of Materials Science and Metallurgy Engineering, University of Pretoria, South Africa.

2 School of Mining Engineering, University of the Witwatersrand, South Africa.

(1) The Southern African Institute of Mining and Metallurgy, 2019. ISSN 2225-6253. Paper received Jun. 2018; revised paper received Aug. 2018. 


\section{Improved ultrafine coal dewatering using different layering configurations}

relationship with the product surface moisture content (Arnold, 1999). The final filter cake moisture is influenced by modification of the coal surface, type of surfactant, type of dewatering device, conditioning time, and the $\mathrm{pH}$ value of the system (Nkolele, 2004).

Modelling of water and coal particle interactions is continually evolving to enable a better understanding of the interactions that occur during dewatering. Tests have proven that the densest packing of spherical particles results in a total void volume of $26 \%$, due to the comparable densities of coal and water (Nkolele, 2004). For smaller coal particle sizes, the voids form capillary cavities filled by water. An increased attraction between the water and the coal surface results, leading to mechanical dewatering mechanisms not being able to adequately remove this water (Nkolele, 2004). Decreasing particle size causes an increased water-exposed surface area. The particle size of the coal is inversely proportional to the final moisture content of the filter cake: finer coal sizes have larger moisture retention (i.e., are more difficult to dewater) than coarser particle sizes (Basim, 1997).

\section{Moisture reduction through blending}

The coal industry often reduces the moisture content of the filter cake by blending high-moisture fine coal with lowmoisture coarse coal. The blending proportions differ depending on the materials used in the colliery. The optimum blend must therefore be individually determined for each plant. Blending increases the permeability of the cake, leading to reduced blinding of the belt filter cloth.

\section{Characteristics of belt filter systems}

Belt filter systems are specifically designed for a high solids capacity. The concentration of solids for the system is determined by the concentration of the primary solids in the feed and further solids that may precipitate during treatment, hence a varying feed solids concentration is experienced. For most sludges fed to belt filter presses, the feed dry solids concentration falls in the range of $1-10 \%$ and the resulting moisture content of the filter cake is the range of $12-50 \%$. The input solids loading depends on the sludge type and the filter media used. This input to the belt filter press is generally measured as the mass of dry solids per unit time per unit belt width. For lower ranges of solids, the feed is normally $40-230 \mathrm{~kg} / \mathrm{h} / \mathrm{m}$ belt width; for higher solids' ranges, the feed increases to $300-910 \mathrm{~kg} / \mathrm{h} / \mathrm{m}$ belt width Dilute feed solids concentrations result in a cake of higher moisture content, while a higher feed solids concentration yields an improved solids filtration rate and a drier end product. The thickness of the cake formed should also be considered when selecting the percentage of solids in the feed. Cake thickness affects the permeability of the filtration mix and thus the filtration rate. Generally, the minimum design discharge cake thickness is 3-5 mm. This size ensures that the cake is thick enough to discharge and easy to remove from the belt (Schonstein, 2008).

\section{Methodology}

\section{Sample preparation}

Sampling was carried out in accordance with the procedure specified by ASTM 2234 (ASTM, 2017a) for gross sample collection from the coal mine Plant 1 and Plant 2 thickener underflow materials. Plant 1 provided the coarse material and Plant 2 the fine material. The sampling position was selected to avoid any mixing of added reagents (such as flocculants) that would be present if samples were taken from the belt filter. The collected coal samples were dried at $105^{\circ} \mathrm{C}$ for 24 hours to remove all moisture. The samples were then broken down using a roller pin and divided into the appropriate sample masses required for testing by means of a rotary splitter.

\section{Particle size distribution}

The particle size distribution (PSD) of each material sample was determined. Wet sieving, using the ASTM D4749 (ASTM, 2017b) procedure, was employed to obtain an accurate representation of size. Each test employed three $500 \mathrm{~g}$ samples from each plant. The PSD analyses were carried out in triplicate to obtain representability. The size distribution ranged from -1000 to $-53 \mu \mathrm{m}$.

\section{Layering configurations}

Figure 1 shows the layering configurations and their descriptors used in this study. The samples from Plants 1 and 2 had different material size distributions and the drainage would differ for different layering configurations. For each of the five layering possibilities, three tests were conducted to determine the relative error. Different layering set-ups were tested to determine the configuration that gave the best dewatering results. This optimum layering set-up was then used for further test work. Each test required a combined mass of $200 \mathrm{~g}$. The appropriate amount of water was then added to obtain the typical underflow solids density of the industrial thickeners of $44 \%$; thus, for $200 \mathrm{~g}$ solids, $454 \mathrm{~mL}$ water was added.

Industrial AP520 C flocculant (Pathlochem) was mixed with the water at 0.05 mass percentage, as used in industry. Filter paper (Econofilt, $240 \mathrm{~mm}$ diameter) was placed on a Buchner vacuum filter, after which the slurries of the various materials were layered in the filter according to the required configuration in such a way as to not disturb the layering. The vacuum filter was switched on and the mass of water removed from the slurries was measured every second for a period of 300 seconds using a load cell (ZEMIC model H3-C3$100 \mathrm{~kg}-3 \mathrm{~B})$.

\section{Optimum blend determination}

Once the most efficient layering configuration was established, this was used to determine the optimum blend for the most efficient moisture removal. The slurries comprised 0, 10, 25, 50, 75, and 100\% Plant 2 material. All tests were carried out in triplicate

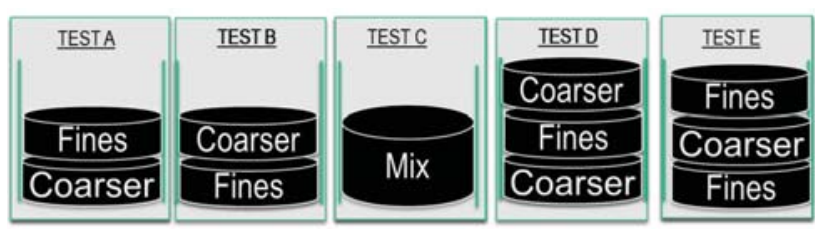

Figure 1-Layering configurations tested, where Plant 1 material represents the coarse particles and Plant 2 material the fine particles 


\section{Improved ultrafine coal dewatering using different layering configurations}

\section{Moisture content analysis of filter cake}

In addition to using load cell measurements to determine the mass of water removed by filtering, the moisture retention of the filter cake was measured by removing the surface moisture by drying, according to the procedure described by ASTM D3302 (ASTM, 2017c). This entailed spreading the sample into tared pans and weighing the pans, after which the sample was dried in an oven at $30^{\circ} \mathrm{C}$ with intermittent stirring until the sample appeared dry. The pan was then removed and the new mass recorded before it was placed back in the oven. This procedure was repeated at 2-hour intervals until the mass change between the intervals was less than $0.1 \%$. The sample was then cooled to ambient temperature, the final mass measured, and the moisture change calculated.

\section{Experimental set-up}

A stand was designed and built, in which the load cell could be placed and connected to the ceramic head of the vacuum filter. A water distribution system was designed to distribute water evenly over the entire layered sample at a low enough rate to prevent mixing of the layers. The experimental equipment and configuration are shown in Figure 2.

\section{Results and discussion}

\section{Particle size distribution}

The PSD was used to characterize the materials used for the experiments. The wet sieving results are shown in Figure 3. The $D_{50}$ values (particle size at which $50 \%$ of the material passed through the sieve) for Plant 1 (coarse) and Plant 2 (fine) materials were $75 \mu \mathrm{m}$ and $34 \mu \mathrm{m}$, respectively.

\section{Sample properties}

Samples were also split out, ground, and subjected to X-ray diffraction (XRD) and X-ray fluorescence (XRF) analysis. $\mathrm{XRD}$ indicated that the higher percentage clay phase in the Plant 2 material was kaolinite. The XRD and XRF results are given in Tables I and II, respectively.

\section{Labelling of experiments}

To best illustrate the layering set-up for the experiments. labels were used that referred to the order in which the samples from Plant $1\left(D_{50}\right.$ of $\left.75 \mu \mathrm{m}\right)$ and Plant $2\left(D_{50}\right.$ of $34 \mu \mathrm{m})$ were configured. Table III shows an explanation of the labelling system used.

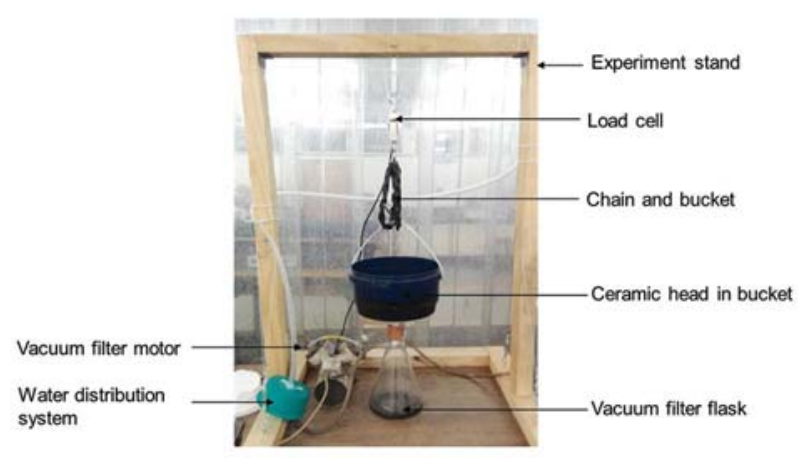

Figure 2-Experimental set-up

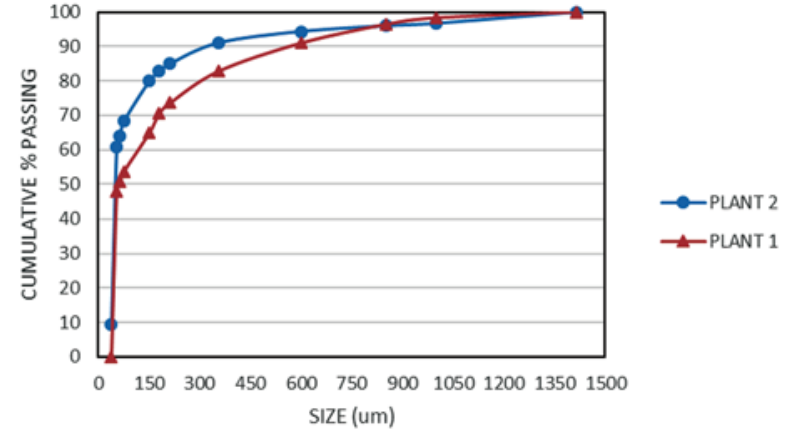

Figure 3-Particle size distributions of Plant 1 and Plant 2 thickener underflow materials as sampled

Table I

X-ray diffraction results

\begin{tabular}{|l|r|c|c|r|l|}
\hline \multicolumn{3}{|c|}{ Plant 1 } & \multicolumn{3}{c|}{ Plant 2 } \\
\hline & Mass\% & 3 $\sigma$ error & & Mass\% & 3 $\sigma$ error \\
\hline Calcite & 2.04 & 0.51 & Calcite & 2.21 & 0.57 \\
Dolomite & 7.81 & 1.17 & Dolomite & 8.91 & 1.2 \\
Kaolinite & 38.17 & 1.35 & Kaolinite & 43.09 & 1.38 \\
Magnetite & 3.76 & 0.42 & Magnetite & 10.49 & 0.57 \\
Pyrite & 3.79 & 0.39 & Pyrite & 2.75 & 0.39 \\
Quartz & 39.89 & 1.29 & Quartz & 27.44 & 1.11 \\
Siderite & 4.54 & 0.63 & Siderite & 5.13 & 0.66 \\
\hline
\end{tabular}

Table II

$\mathrm{X}$-ray fluorescence results

\begin{tabular}{|l|c|c|r|r|}
\hline & \multicolumn{2}{|c|}{ SARM 49 } & \multirow{2}{*}{ Plant 1 } & \multirow{2}{*}{ Plant 2 } \\
\cline { 2 - 3 } & Certified & Analysed & & \\
\hline $\mathrm{SiO}_{2}$ & 99.6 & 99.70 & 17.90 & 18.40 \\
$\mathrm{TiO}_{2}$ & 0.01 & 0.00 & 0.40 & 0.60 \\
$\mathrm{Al}_{2} \mathrm{O}_{3}$ & 0.05 & 0.01 & 7.01 & 8.69 \\
$\mathrm{Fe}_{2} \mathrm{O}_{3}$ & 0.05 & 0.01 & 2.54 & 5.97 \\
$\mathrm{MnO}_{\mathrm{MgO}}$ & 0.01 & 0.00 & 0.06 & 0.08 \\
$\mathrm{CaO}$ & 0.05 & 0.01 & 0.53 & 0.65 \\
$\mathrm{Na}{ }_{2} \mathrm{O}$ & 0.01 & 0.01 & 1.36 & 1.74 \\
$\mathrm{~K}_{2} \mathrm{O}$ & 0.05 & 0.02 & 0.04 & $<0.01$ \\
$\mathrm{P}_{2} \mathrm{O}_{5}$ & 0.01 & 0.01 & 0.39 & 0.28 \\
$\mathrm{Cr}_{2} \mathrm{O}_{3}$ & 0 & 0.03 & 0.09 & 0.10 \\
$\mathrm{NiO}$ & 0 & 0.00 & 0.01 & 0.02 \\
$\mathrm{~V}_{2} \mathrm{O}_{5}$ & 0 & 0.01 & 0.01 & 0.03 \\
$\mathrm{ZrO}$ & 0 & 0.00 & 0.01 & 0.02 \\
$\mathrm{SO}_{3}$ & 0 & 0.01 & 0.02 & 0.03 \\
$\mathrm{BaO}$ & 0 & 0.00 & 0.08 & 0.06 \\
$\mathrm{CuO}$ & 0 & 0.00 & 0.04 & $<0.01$ \\
$\mathrm{ZnO}$ & 0 & 0.00 & $<0.01$ & $<0.01$ \\
$\mathrm{SrO}$ & 0 & 0.00 & $<0.01$ & 0.01 \\
$\mathrm{LOI}_{\mathrm{Total}}$ & 0 & 0.00 & 0.02 & 0.02 \\
& 0 & 0.10 & 69.50 & 63.20 \\
& 100 & 99.93 & 100.00 & 99.91 \\
\hline
\end{tabular}

\section{Moisture retention and drainage rates}

The results for the amount of water removed for the different layering configurations are shown in Figure 4. Some noise in the data occurred due to vibration of the vacuum filter motor on the laboratory bench. For the specified filtration time of 300 seconds, higher drainage values were achieved when the Plant 2 (fine) material was placed first on the filter paper. The 


\section{Improved ultrafine coal dewatering using different layering configurations}

Table III

Explanation of experiment labels

\begin{tabular}{|l|c|}
\hline Label & Explanation \\
\hline $\begin{array}{l}\text { Plant 1 } \\
\text { Plant 2 }\end{array}$ & $\begin{array}{c}\text { Only Plant 1 sample used } \\
\text { Only Plant 2 sample used }\end{array}$ \\
Plant 1-2 & $\begin{array}{c}\text { Plant 1 sample on top with Plant 2 sample layered at the bottom } \\
\text { Plant 2-1 }\end{array}$ \\
Plant 1-2-1 & Plant 2 sample on top with Plant 1 sample layered at the bottom \\
Plant 2-1-2 & Plant 1 sample on top with Plant 2 sample in the middle and Plant 1 sample layered at the bottom \\
\hline
\end{tabular}

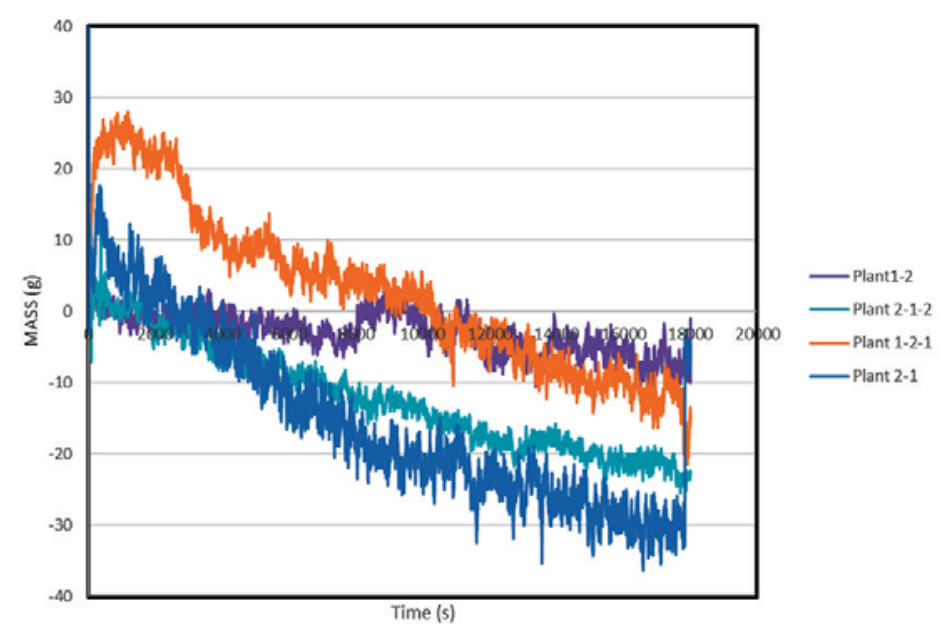

Figure 4-Load cell measurements showing rate of mass loss of water under different filtration layering configurations

Plant 2-2 configuration gave the highest drainage rate. The drainage rates decreased when Plant 1 (coarse) material was layered at the bottom on the filter. As expected, using only Plant 2 (fine) material resulted in a very slow drainage rate.

The data shown in Figure 4 followed an exponential decay trend for the drainage rates. The Plant 1-2-1 configuration showed an initial increase in moisture drainage. It is theorized that the water drained through the upper Plant 1 (coarse) layer and was then trapped in the middle Plant 2 (fine) layer, which prevented further draining until the force from the vacuum became sufficient to drain the water through the bottom Plant 1 coarse layer; the drainage rate then started increasing. Table IV details the final results. The Plant 2-1 and Plant 2-1-2 layering configurations gave the best drainage rates, while those in which the Plant 1 material was placed at the bottom gave the least-desired results.

Layering of Plant 2 (fine) material at the bottom of the filter cake resulted in $22 \%$ moisture retention; layering Plant 1 (coarse) material at the bottom gave 30\% moisture retention. This large difference can be explained by the size differences between the two materials. When Plant 2 material was at the top, it started to settle in the gaps formed by the coarser Plant 1 material. The finer material then trapped the water and formed a layer of fine wet material. This layer did not settle to the bottom of the filter cake and the suction power of the vacuum filter was not adequate to extract this trapped water.
When Plant 2 (fine) material was layered at the bottom, most water seeped quickly through the gaps formed in the Plant 1 material to the Plant 2 layer. The Plant 1 material did not settle into the Plant 2 layer because the gaps between the latter particles were too small. The water then became trapped in the bottom Plant 2 layer. The fine material did not trap the water in the Plant 2 layer that was placed directly on the filter paper, and the force of the vacuum was strong enough to extract more of this water. The best layering configuration was therefore to use Plant 2 (fine) material at the bottom. Both the Plant 2-1 and Plant 2-1-2 configurations offered improvement; however, to minimize complications in industrial application, it would be easier to have a single layer of each particle size range. The Plant 2-1 configuration was therefore selected as optimum.

Table IV

Results of layering experiments

\begin{tabular}{|l|c|c|c|}
\hline $\begin{array}{l}\text { Layering } \\
\text { configuration }\end{array}$ & $\begin{array}{c}\text { Total mass of } \\
\text { water removed } \mathbf{( g )}\end{array}$ & $\begin{array}{c}\text { Drainage rate } \\
\mathbf{( m L / s )}\end{array}$ & $\begin{array}{c}\text { Moisture retained } \\
\mathbf{( \% )}\end{array}$ \\
\hline Plant 2 & 337.83 & 1.13 & 26 \\
Plant 1 & 339.3 & 1.13 & 25 \\
Plant 2-1 & 356.08 & 1.19 & 22 \\
Plant 1-2 & 317.07 & 1.06 & 30 \\
Plant 2-1-2 & 341.13 & 1.14 & 25 \\
Plant 1-2-1 & 323.61 & 1.08 & 29 \\
\hline
\end{tabular}




\section{Improved ultrafine coal dewatering using different layering configurations}

It is worthy of note that the $25 \%$ and $26 \%$ moisture retentions reported for the individual Plant 1 and Plant 2 materials, respectively (Table I), were close to the values currently measured on an industrial scale. The experimental results are therefore considered to be comparable to projected industry performance.

\section{Filter cake stability}

The quality of the filter cake after dewatering is very important with regard to its further processing. If the cake is too wet, it will be heavy and have the characteristics of sludge, making it difficult for the dewatered material to be transported on the mine conveyor systems. Figures $5 \mathrm{a}$ to $5 \mathrm{c}$ show considerable differences in the final filter cakes: the cake from the Plant 1-2 configuration still had water lying on the top; the cake resulting from the Plant 2 configuration did show moisture retention and a tendency to be sludgy; that resulting from the Plant 2-1 configuration was much sturdier and had a visually drier appearance.

\section{Water quality of layers}

Water extracted from the belt filter is recycled to the process plant so its quality is important. Figures $6 \mathrm{a}$ to $6 \mathrm{c}$ show large differences in the water qualities produced from the Plant 2 , Plant 1-2, and Plant 2-1 configurations. For the Plant 1-2 configuration, a large amount of fines washed through the filter paper with the water, which resulted in poor water quality and would cause a build-up of ultrafine material in processes where the recycled water is utilized.

\section{Influence of proportion of fines on water removal}

To determine the optimum blend of the two materials, the Plant 2-1 layering configuration was employed with different proportions of fines in the bottom layer. The amount of water removed was plotted against the percentage fines, as shown in Figure 7. The data is given in Table V. A fitted linear equation was obtained and the Microsoft Excel Solver function was used to determine the optimum percentage of Plant 2 fines that should be employed in this layering configuration.

Using the best-fit quadratic relationship indicated in Figure 7, it was determined that the optimum Plant 2-1

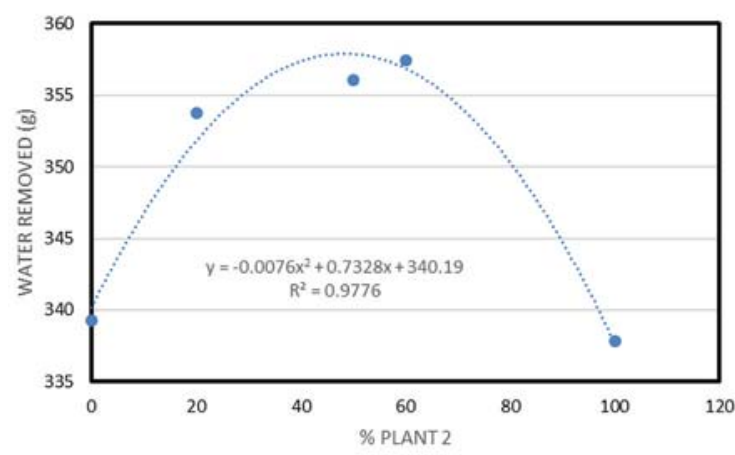

Figure 7-Total water removal as a function of percentage fines when using the Plant 2-2 filtration configuration

Table $\mathrm{V}$

Results for percentage fines addition using Plant 22 configuration

\begin{tabular}{|l|c|c|c|}
\hline $\begin{array}{l}\text { Proportion of Plant 2 } \\
\text { (fine) material (\%) }\end{array}$ & $\begin{array}{c}\text { Total mass of } \\
\text { water removed (g) }\end{array}$ & $\begin{array}{c}\text { Drainage } \\
\text { rate (mL/s) }\end{array}$ & $\begin{array}{c}\text { Moisture } \\
\text { retained (\%) }\end{array}$ \\
\hline 0 & 339.3 & 1.13 & 25 \\
20 & 353.75 & 1.18 & 22 \\
50 & 356.08 & 1.19 & 22 \\
60 & 357.44 & 1.19 & 21 \\
100 & 337.83 & 1.13 & 26 \\
\hline
\end{tabular}

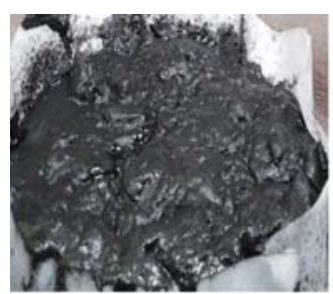

a)

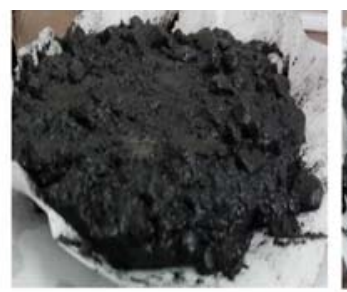

b)

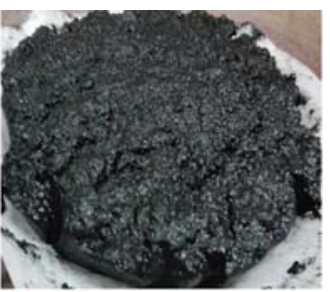

c)

Figure 5-Photographs of final filter cakes produced using (a) Plant 2, (b) Plant 1-2, and (c) Plant 2-1 filtration configurations

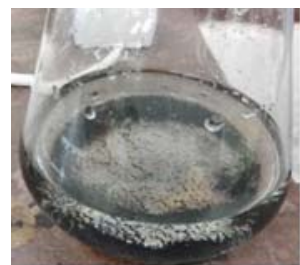

a)

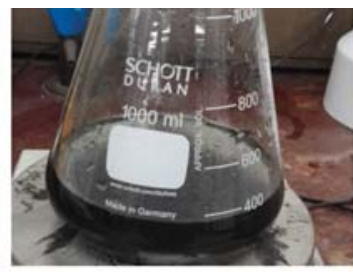

b)

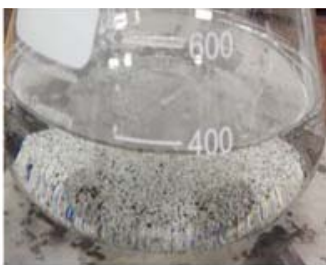

c)

Figure 6-Quality of filtered water produced by (a) Plant 2, (b) Plant 1-2, and (c) Plant 2-1 filtration configurations 


\section{Improved ultrafine coal dewatering using different layering configurations}

layering required that $48 \%$ by mass of Plant 2 material should be used for the bottom layer. This is expected to give $21 \%$ water retention in the final cake, as proven in this test work. However, as shown in Table II, there is a range of percentage fines - from $20 \%$ to $60 \%$ - for which moisture removal would be efficient. Industrial applications will therefore have some leeway if the process parameters fall within this range. A comparison of the PSD for the optimum blend with those of Plants 1 and 2 is presented in Figure 8. The optimum Plant 2-1 blend has a $D_{50}$ of $53 \mu \mathrm{m}$.

\section{Conclusions}

A South African coal mine suffers from poor belt filtration performance when treating fine material originating from the Plant 2 thickener underflow. This study evaluated the filtration characteristics and water quality produced using various blends and layering configurations of coarser Plant 1 material with the fine Plant 2 material. The experimental results showed that mixing Plant 1 and Plant 2 materials gave improved dewatering efficiency compared with Plant 2 material alone. A layering configuration with the fine material placed directly on the filter cloth and the coarse material layered above gave the best filtration characteristics. The optimum blend for this industrial application contained $48 \%$ of the Plant 2 fines. The existing Plant 1 and Plant 2 arrangements can be retained, but the materials currently fed to the two plants should be appropriately split to ensure sufficient dewatering and plant capacity.

\section{Acknowledgements}

This work was financially supported by EXXARO. This manuscript was edited for publication by Dr Kathryn Sole (University of Pretoria). Mrs J. Dykstra carried out the XRF analyses and Mrs W. Grote the XRD at Stoneman (University of Pretoria).

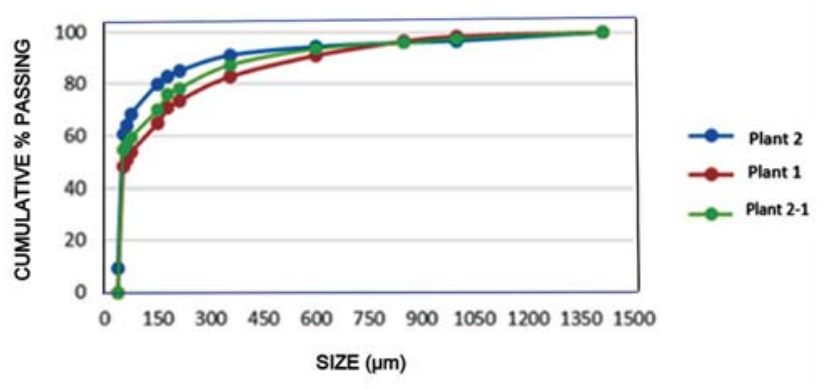

Figure 8-Comparison of particle size distributions of feeds to Plant 1, Plant 2, and optimized Plant 2-1 layer configurations

\section{References}

ARNold, B. 1999. Simulation of dewatering devices for predicting moisture content of coal. Coal Preparation, vol. 20. pp. 35-54.

ASTM. 2017a. D2234. A. Standard practice for collection of a gross sample of coal. ASTM International, West Conshohocken, PA.

ASTM. 2017b. D4749. Standard test method for performing the sieve analysis of coal and designating coal size. ASTM International, West Conshohocken, PA.

ASTM. 2017c. D3302. A. Standard test method for total moisture in coal. ASTM International, West Conshohocken, PA.

BASI, G. 1997. Fine coal dewatering. Master's thesis, Virginia Tech State University. https://vtechworks.lib.vt.edu/handle/10919/35680

DE KoRTe, G. 2008. Dewatering of ultra-fine coal with filter presses. Coaltech, Pretoria.

Kenney, M.E. 1994. Coal dewatering. US patent 5.346.630.

Laboratories, E.G. 2016. PSD of GG8 and GG2. Exxaro GG, Lephalale, South Africa.

LE Roux, M.E.A. 2005. The optimization of an improved method of fine coal dewatering. Minerals Engineering, vol. 18, no. 9. pp. 931-934.

NKolele, A. 2004. Investigations into the reduction of moisture in final coal by plant tests with surfactants. Journal of the South African Institute of Mining and Metallurgy, vol. 104, no. 3. pp. 171-176.

SchonsteIn, P. 2008. Horizontal vacuum belt filters in the mining and chemical industries. Filtration and Separation, vol. 28, no. 2. pp. 121-122.

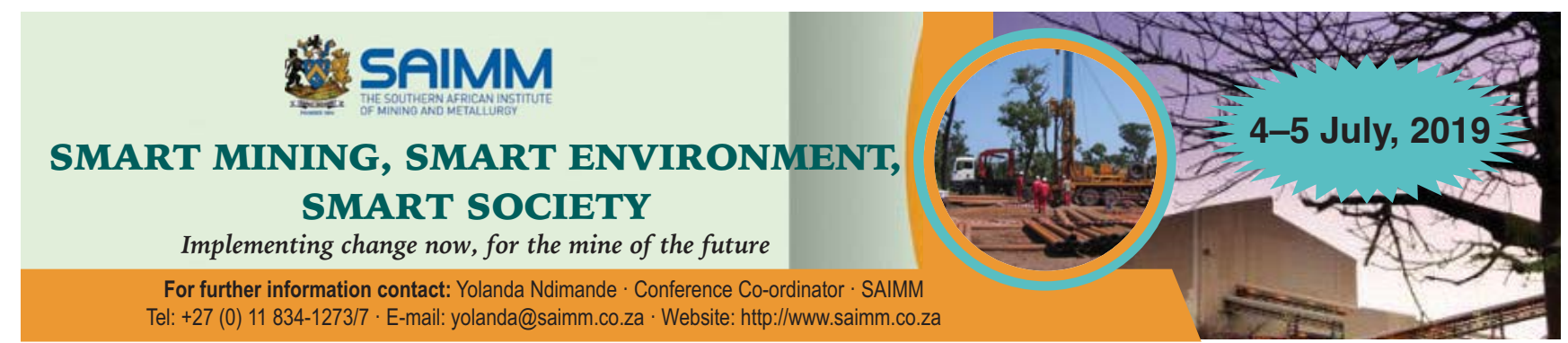

Background

Society in general, and the economy in particular, is evolving at breakneck speed. Old jobs are being lost and new ones are constantly being created. It is likely that mines developed in the next ten years will have a very different staff complement to those currently in production. It is also clear that we are at tipping points for climate systems and for biodiversity: the challenges facing the extractive sector in the coming decades are likely to be much greater than anything in the past century. What does this mean for environmental management? How should we be planning mines to reduce environmental footprints? What skills do we need to do this? Which energy sources will be available and will they have an impact on production? Can we close mines in a way that ensures that viable post-mining economies can be established? This conference bridges the gap between practitioners and decision-makers and managers in both the public and private sectors. The intention is to transfer knowledge and to debate the big issues facing regulators, mining companies, labour, and communities in a way that identifies solutions. The conference will consist of a number of invited keynote speakers who will focus on strategic issues, with the possibility of a workshop included. 